\title{
Two New Records of Eupithecia (Lepidoptera: Geometridae) from Korea
}

\author{
Sei-Woong Choi ${ }^{1, *}$ and Sung-Soo Kim² \\ ${ }^{1}$ Department of Environmental Education, Mokpo National University, \\ Muan, Jeonnam 534-729, Korea \\ ${ }^{2}$ Research Institute for East Asian Environment and Biology, Seoul, Korea
}

\begin{abstract}
We report two species of Eupithecia for the first time from Korea. Two females of Eupithecia sophia Butler were collected from Jejudo Island and Sobaeksan Mt., Danyang, and two males of Eupithecia niphonaria Inoue were collected from Duryunsan Mt., Haenam. Up to now, a total of 51 species of Eupithecia are recorded from Korea. Diagnosis and description of each species are given with the figures of genitalia.
\end{abstract}

Key words: Geometridae, Eupithecia, Lepidoptera, taxonomy, Korea

\section{INTRODUCTION}

The genus Eupithecia Curtis is one of the most species-rich taxa of Lepidoptera, comprising more than 1,300 species worldwide (Scoble, 1999). They can be recognized by slender forewing with projected apex, indistinct basal, ante- and postmedial transverse lines with definite discal spot on forewing, two pairs of spurs on hindtibia (Mironov, 2003). The eighth male abdomen has a distinct sclerotized plate $(=\mathrm{oc}-$ tave) on sternite. The male genitalia are recognized by the membranous, tapering uncus with one or two tips, slender membranous valva often with ventral process, labidies with anterior arms apically digitiform, juxta broadest transversely with two narrow apical lobes, and aedeagus with one or more variously shaped cornuti (Mironov, 2003). The female genitalia are recognized by membranous papillae anales, ductus bursae with a well-developed colliculum, and corpus bursae covered with numerous signa and different position of ductus seminalis.

In Korea, Herz (1904) first described 4 species of Eupithecia. Since Herz, a total of 49 species of Eupithecia are recorded from the Korean Peninsula (Oh, 1992, 1993; Shin, 1996; Byun et al., 1998; Choi, 2003). The purpose of the present study was to report two additional species of Eupithecia from Korea.

Examination of adults including male and female genitalia refers to Scoble (1992). Abbreviations are as follows: JN: Province Jeollanam-do, JJ: Province Jeju-do, CB: Province

\footnotetext{
*To whom correspondence should be addressed

Tel: 82-61-450-2783, Fax: 82-61-453-4843

E-mail: choisw@mokpo.ac.kr
}

Chungcheongbuk-do, MNU: Mokpo National University.

\section{SYSTEMATIC ACCOUNTS}

Order Lepidoptera Linnaeus, 1758

Family Geometridae Stephens, 1829

Subfamily Larentiinae Duponchel, 1845

Genus Eupithecia Curtis, 1825

Eupithecia Curtis, 1825: 64. Type species: Phalaena absinthiata Clerck.

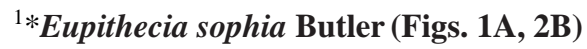

Eupithecia sophia Butler, 1878: 444 (TL: JAPAN, Yokohama).

Eupithecia jezonica Matsumura, 1927: 184 (TL: JAPAN, Hokkaido).

Eupithecia sophia ab. simplex Dietze, 1910: pl. 361.

Eupithecia sophia ab. griseipars Prout, 1938: 194.

Material examined. [CB] 1 우 Sobaek san Mt., CB: Danyang, $128^{\circ} 31^{\prime} \mathrm{E}, 37^{\circ} 01^{\prime} \mathrm{N}, 280 \mathrm{~m}, 21$ Jul. 2005 (S.-W. Choi); [JJ] 1 우 Tamra University, JJ: Seoguipo, 24 Sep. 2008 (S.-S. Kim).

Diagnosis. This species is externally similar to Eupithecia tabidaria Inoue in the smaller wingspan and central fascia of forewing, but can be distinguished by the medial whitish band on central fascia and more slanted postmedial line of forewing and basally and medially whitish hindwing. The male genitalia can be diagnosed by the lack of uncus, simple membranous valva with smooth ventral margin, and slender aedeagus with a short stick-like cornutus (Inoue, 1979). The

\footnotetext{
$1 *$ 꼬마애기물결자나방 (신칭)
} 


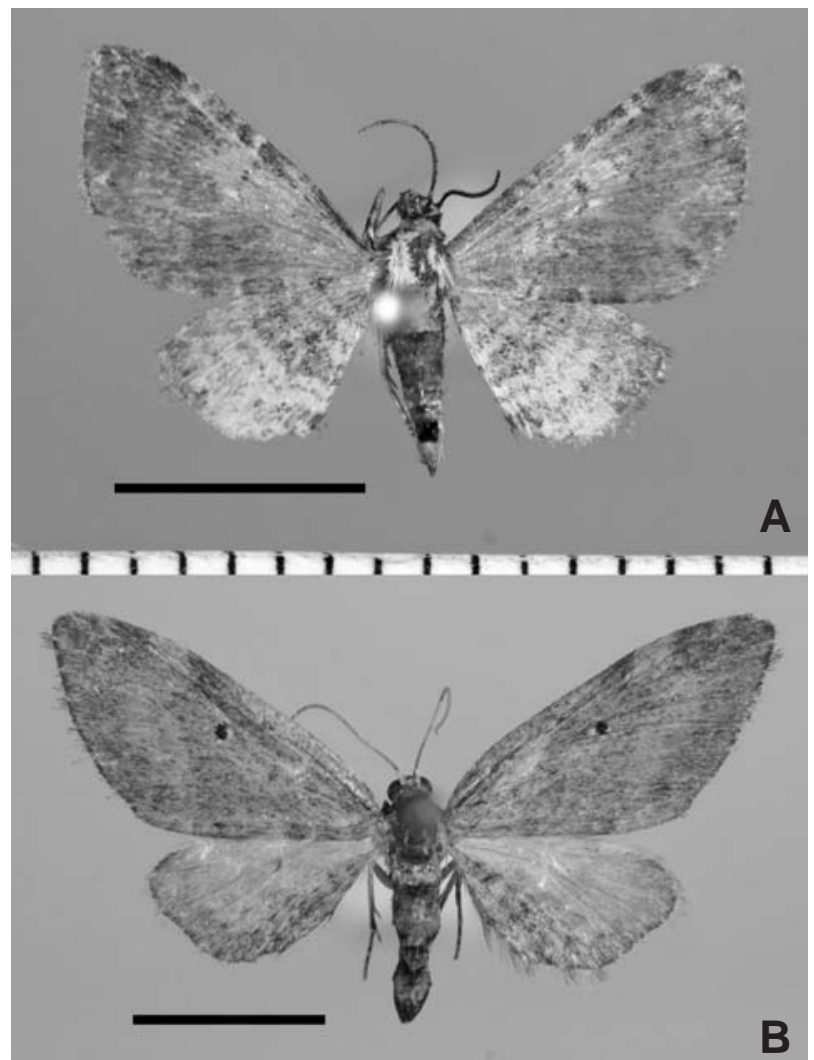

11111111111111111111

Fig. 1. Adults of Eupithecia new to Korea. A, E. sophia Butler; $B, E$. niphonaria Inoue. Scale bars $=5 \mathrm{~mm}(\mathrm{~A}, \mathrm{~B})$.

female genitalia can be diagnosed by the long posterior apophyses, simple ostium bursae, long ductus bursae with a colliculum and oval corpus bursae with a relatively thick ductus seminalis near the junction of ductus bursae.

Description. Wingspan 13-14 mm. Antennae filiform; frons broad, trapezoidal, mixed with whitish and dark brownish scales; labial palpi moderate, being the same as the eye diameter, largely expanded at middle part. Body and legs covered with whitish scales. Forewing ground color grayish, central fascia with multiple transverse lines, medially whitish and dark discoidal dot, one areole; subtermen with dark grayish and whitish line; termen dark grayish. Hindwing ground color whitish; basal, medial and subtermen with grayish transverse lines.

Female genitalia (Fig. 2A). Simple papillae anales; posterior apophyses long, about 1.5 times of anterior apophyses; ostium bursae simple, membranous; ductus bursae long, about the longitudinal diameter of corpus bursae, membranous, anterior with a colliculum; corpus bursae ovate, cover- ed with two large signa patches; ductus seminalis relatively thick, located near the junction between ductus and corpus bursae.

Biology. The species is multivoltine in Japan (Inoue, 1979). Distribution. Korea, Japan, West China.

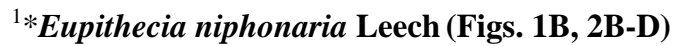

Eupithecia niphonaria Leech, 1897: 68 (TL: JAPAN).

Eupithecia draudti Dietze, 1913: 148, pl. 85: 962, 963 (TL: JAPAN, Tokyo).

Eupithecia corticosa Prout, 1914: 296 (TL: JAPAN, Tokyo).

Eupithecia maenamii Inoue, 1965: 105 (TL: JAPAN, Takaosan, Tokyo).

Material examined. [JN] $2 \sigma^{\top 7}$ Duryun san Mt., JN: Haenam, $126^{\circ} 37^{\prime} \mathrm{E}, 34^{\circ} 28^{\prime} \mathrm{N}, 28$ Apr. 2003 (S.-W. Choi).

Diagnosis. This species is externally similar to E. clavifera Inoue in the dark grayish transverse central fascia of forewing, but can be distinguished by the larger wingspan, relatively broad and paler subtermen of forewing. The male genitalia of $E$. niphonaria are diagnosed by the bifurcated tip of uncus, well developed subscaphium, slender valva with broad sacculus and large saccus. The male genitalia are similar to E. proterva Butler in the shape of sacculus and aedeagus with vesica, but can be distinguished by the shape of bifurcated uncus and less projected sacculus of valva and the rounded anterior arm of octave on male $8^{\text {th }}$ sternite. The female genitalia of E. niphonaria can be diagnosed by the simple papillae anales, long posterior apophyses, about twice the anterior apophyses, half-rounded sclerotized ostium bursae, short ductus bursae with a colliculum and ovate corpus bursae with a densely covered signa and centrally located ductus seminalis (Inoue, 1979).

Description. Wingspan 18-21 mm. Antennae filiform; frons relatively narrow, mixed with dark ocherous and pale ocherous scales; labial palpi covered with dark ocherous scales, medially with long hairs, slightly longer than eye diameter. Body and legs covered with whitish scales. Forewing ground color ocherous; basal and centrally dark ocherous or grayish, postmedial line costally concave, medially slightly projected and slanted, discoidal dot blackish, one areole; ocherous between central fascia and subtermen; termen dark grayish. Hindwing whitish; centrally with multiple transverse lines; termen dark grayish.

Male abdomen and genitalia (Figs. 2B-D). Abdominal $8^{\text {th }}$ sternite slender octave with a pair of broad anterior arms and a pair of minute posterior tip; uncus tip bifurcated, tapering; subscaphium developed; labidies slender, inwardly curved and medially united; juxta broad, medially strongly project-

\footnotetext{
$1 *$ 참나무애기물결자나방 (신칭)
} 

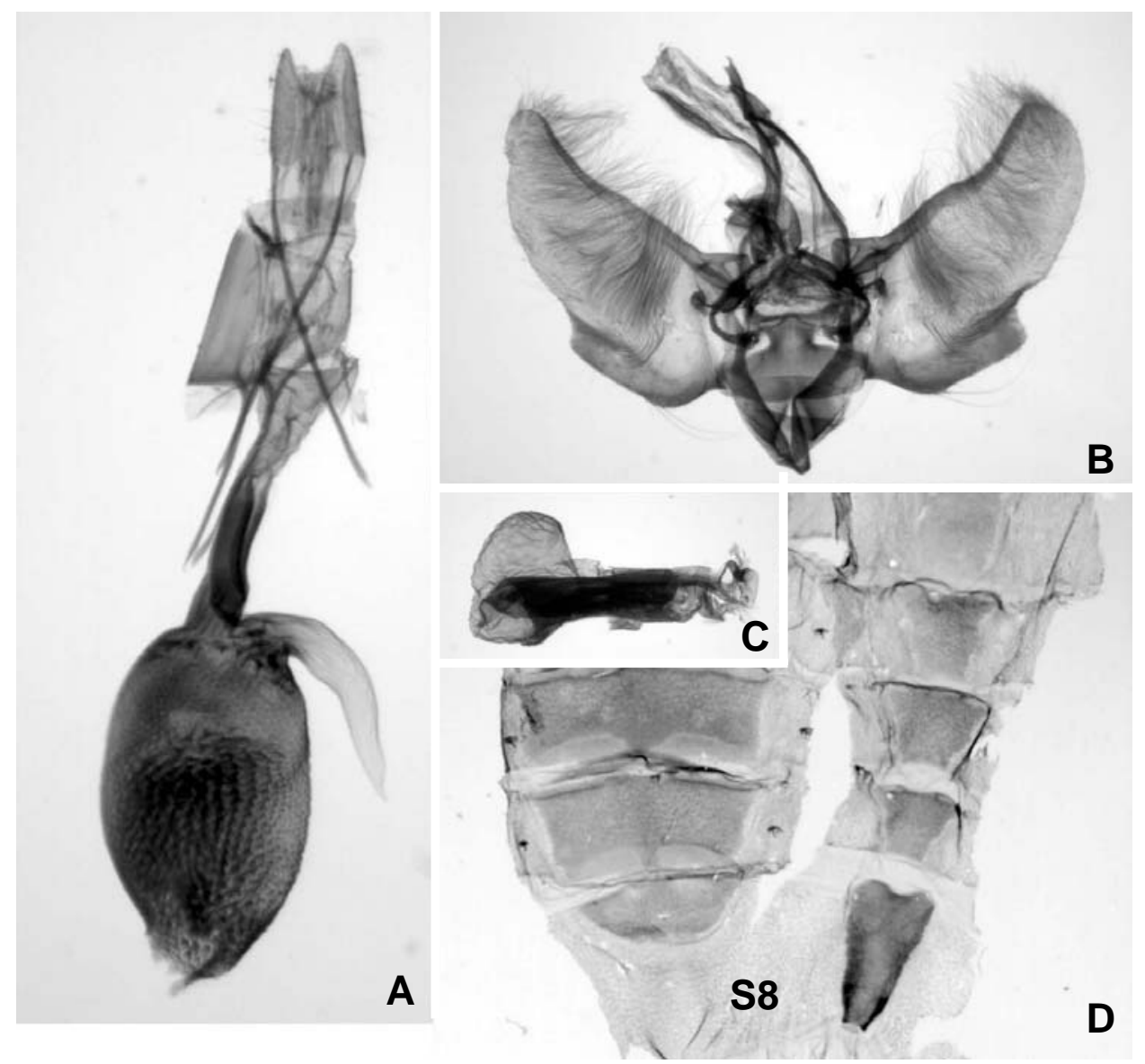

Fig. 2. Male and female genitalia. $A$, female genitalia of E. sophia; $B$, male genitalia of E. niphonaria; $C$, aedeagus of $E$. niphonaria; $\mathrm{D}$, male abdomen of E. niphonaria. S8, $8^{\text {th }}$ sternite.

ed. Valva membranous, slender; costa thinly sclerotized, basally strongly expanded; sacculus broadly expanded process; saccus anteriorly strongly projected. Aedeagus slender; vesica tubular with a line of minute cornuti.

Biology. This species is flying in April and feeds on Quercus phyllyraeoides (Fagaceae) (Inoue, 1979).

Distribution. Korea, Japan.

\section{ACKNOWLEDGEMENTS}

This study was partly supported by the Korea Science and Engineering Foundation (KOSEF) grant funded by the Korea Government (MEST) (R01-2008-000-20671-0).

\section{REFERENCES}

Butler, A.G., 1878. Descriptions of new species of Heterocera from Japan. Part 3. Geometrites. Ann. Mag. Nat. Hist., (5)1: 440-452.

Byun, B.K., C.S. Kim, and J.K. Kim, 1998. Eupithecia abietaria debrunneata Staudinger (Lepidoptera: Geometridae) feeding on the cone of the Korean white pine new to Korea. Korean J. Entomol., 28: 341-343.

Choi, S.W., 2003. Faunistic study of the Larentiinae (Lepidoptera: Geometridae) of North Korea. Ins. Koreana, 20: 313 342.

Curtis, J., 1825. British Entomology; being Illustrations and Descriptions of the Genera of Insecta found in Great Britain and Ireland: Containing coloured Figures from Nature of the Most Rare and Beautiful Species, an in Many Instances of the Plants Upon Which They are Found. British Entomology, 2: 64 .

Dietze, K., 1910. Biologie der Eupithecien. I. Berlin, Taf. 1-82.

Dietze, K., 1913. Biologie der Eupithecien. II. Berlin, pp. 1-173, 86 Tafs.

Herz, O., 1904. Lepidoptera von Korea. Noctuidae and Geometridae. Ezheg. Zool. Muz., 9: 263-390. 
Inoue, H., 1965. Descriptions and records of some Japanese Geometridae (IV). Tinea, 7: 102-111.

Inoue, H., 1979. Revision of the genus Eupithecia of Japan, Part 1 (Lepidoptera: Geometridae). Bull. Fac. Domestic Sci., Otsuma Woman's Univ., 15: 157-224.

Leech, J.H., 1897. On Lepidoptera Heterocera from China, Japan and Korea. Ann. Mag. Nat. Hist., (6)20: 65-248, pls. 7-8.

Matsumura, S., 1927. Geometrid-Moths collected on Mt. Daisetsu, with Descriptions of new Species. Ins. Matsumurana, 1: 182-187.

Mironov, V., 2003. The Geometrid moths of Europe. Volume 4. Apollo Books, Stenstrup, pp. 1-464.

Oh, S.H., 1992. Taxonomic revision of the genus Eupithecia (Lepidoptera: Geometridae: Larentiinae) from Korea (I). Korean J. Appl. Entomol., 31: 461-474.

Oh, S.H., 1993. Taxonomic revision of the genus Eupithecia (Lepidoptera: Geometridae: Larentiinae) from Korea (II). Korean J. Appl. Entomol., 32: 440-449.
Prout, L.B., 1914. Geometridae. In Seitz, A., ed., The Macrolepidoptera of the World. Volume 4. Verlag des Seitzschen Werkes, Stuttgart, pp. 274-297.

Prout, L.B., 1938. Geometridae. In Seitz, A., ed., The Macrolepidoptera of the World. Volume 4. Supplement. Verlag des Seitzschen Werkes, Stuttgart, pp. 254-766.

Scoble, M.J., 1992. The Lepidoptera, form, function and diversity. Oxford University Press, Oxford, pp. 1-404.+4 pls.

Scoble, M.J., 1999. Geometrid moths of the World. A Catalogue (Lepidoptera, Geometridae). Volume 1. CSIRO and Apollo Books, Stenstrup, pp. 326-378.

Shin, Y.H., 1996. Synonymic list and distribution of the Geometridae of Korea (Lepidotpera). Center for Insect Systematics, Chuncheon, pp. 60-66. 